\title{
VĚČNÝ NÁVRAT A PERIODICKÝ ČAS VE STOICKÉ FILOSOFII
}

\section{Jean-Baptiste Gourinat}

Výraz ewige Wiederkunft - věčný návrat - pochází od Nietzscheho. Jedná se o jeden z klíčových pojmů jeho pozdní filosofie, jak dokazují přípravné poznámky z roku 1888 pro spis Vưle $k$ moci, jehož poslední část měla být tomuto pojmu věnována. V Ecce homo, v souvislosti s tím, jak se toto téma objevuje ve Zrození tragédie, Nietzsche připisuje jeho autorství Hérakleitovi a se sebezapřením jej přiznává i stoikům: stoa, jak píše, „má toho stopy“.2

Jakkoli Hérakleitos představuje pro tuto nauku inspirační zdroj, jedná se ve skutečnosti o nauku stoickou. V hrubých obrysech je to právě tato nauka, jejíž shrnutí vypracované Ariem Didymem nalezneme v textu, který nám předal Stobaios:

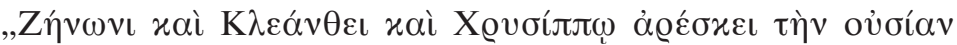

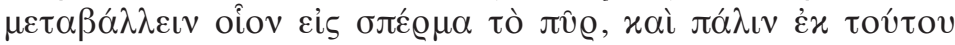

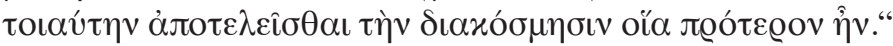

„Zénón, Kleanthés a Chrysippos se domnívají, že se substance proměňuje $v$ oheň, jako by se znovu stávala semenem, a že odtud se znovu naplňuje uspořádání světa tak, jak bylo předtím.“3

Tato nauka, společná třem prvním scholarchům stoické školy, tvrdí, že nej-

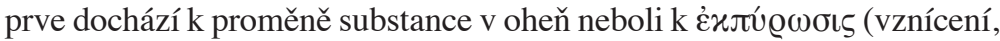

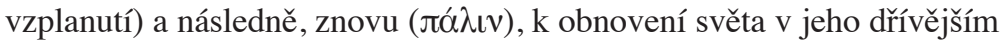
uspořádání. Podle mnohých svědectví dospívá toto „opětné uspořádání“ až k týmž jednotlivcům a týmž událostem. Tento návrat je „věčný“, protože

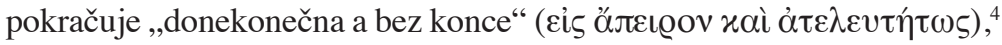

1 J.-B. Gourinat, Éternel retour et temps périodique dans la philosophie stöcienne, in: Revue philosophique de la France et de l'étranger, 2, 2002, str. 213-227.

2 F. Nietzsche, Ecce homo, přel. J. Fischer, Olomouc 2001, str. 61. - Pozn. přek1.

3 Arios Didymos u Stobaia, Ecl. I,20,171 Wachsmuth (= DK 36; SVF I,107; SVF II,596).

4 Nemesios, De nat. hom., kap. 38, Morani (= SVF II,625). 


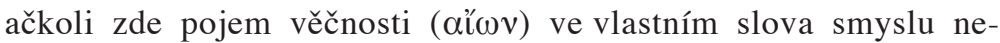

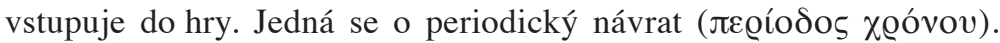

Tato nauka se u stoiků jeví jako jedna z „,nejpodivnějších“ a „nejabsurdnějších", 5 a to tím spíše, že argumenty pro ni - které byly podle názorů stoiků samých „dialektickými nutnostmi“ ${ }^{\text {“6 }}$ - se nám celkem vzato téměř nedochovaly. Nauka byla kritizována již ve starověku. Jejími nejzarytějšími odpůrci byli někteří křest’anští autoři, jako Tatian, který

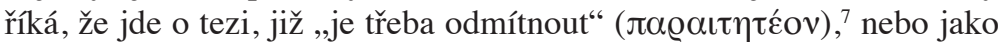
Órigenés ${ }^{8}$ podle něhož pokud by byla tato nauka pravdivá, rušila by to,

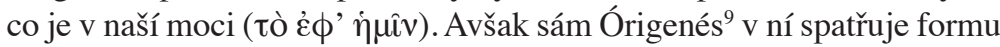
nauky o vzkřríšení a využívá této stoické nauky, aby ukázal, že vzkřrišení není tak absurdní, jak tvrdí Kelsos. ${ }^{10}$ Lactantius shledává tuto nauku „více hodnou doporučení“ nežli pýthagorejskou metempsychósis. ${ }^{11}$ Postoj křest’anských autorů k této nauce je tedy nejednoznačný: nezdá se jim příliš doporučeníhodná, ale přece jen má nejblíž k nauce o vzkř̌íšení.

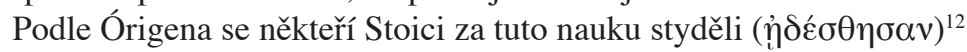
a pokoušeli se „ošetřit“ absurdnosti v ní obsažené. ${ }^{13}$ Několik stoiků se

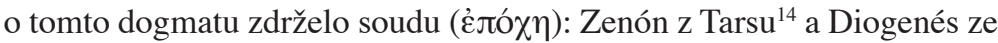
Seleukie..$^{15}$ Dva další je zavrhli: Boéthos ze Sídónu a Panaitios. ${ }^{16}$ Stoikové $v$ něm tedy spatřovali jisté obtíže, nepřijímali je neuváženě, nýbrž po několik generací je důkladně rozebírali. Jádro této debaty je navždy ztraceno. Přesto se můžeme pokusit učinit si o ní představu podle svědectví, která se nám zachovala u odpůrců stoiků.

5 J. Barnes, La doctrine du retour éternel, in: J. Brunschwig (vyd.), Les Stö̈ciens et leur logique, Paris 1978, str. 4; A. Long, The Stoics on World-Conflagration and Everlasting Recurrence, in: R. Epp (vyd.), Spindel Conference 1984: Recovering the Stoics, Southern Journal of Philosophy, 23, Supplement, 1985, str. 13.

6 Órigenés, Contra Cels. V,23 Borret.

7 Tatian, Orat. ad Graec., 3,25 Whittaker.

8 Órigenés, Contra Cels. IV,67.

9 Tamt. V,20.

10 Tamt. IV,12.

11 Lactantius, Div. instit. VII,23 Brandt (= SVF II,263).

12 Órigenés, Contra Cels. V,20.

13 Tamt. IV,68.

14 Eusebios, Praep. evan. XV,18,3 Des Places (= DK 36; SVF III, Zen. Tars. 5).

15 Filón Alexandrijský, De aet. mundi, 77 (= SVF III, Diog. 27).

16 Tamt. (= SVF III, Boeth. 7; Panaitios, 131). 


\section{Nauka}

\subsection{Slovník}

Někteří moderní komentátoři ${ }^{17}$ používají termín „palingeneze“ ( $\pi \alpha \lambda$ i $\gamma \varepsilon v \varepsilon \sigma i ́ \alpha)$. Tento termín se objevuje relativně často, uvážíme-li malé množství zachovaných zdrojů , a podpírá jej stoická autorita Marca Aurelia ${ }^{18} \mathrm{i}$ autorita, také pravděpodobně stoická, Aria Didyma citovaného Eusebiem. ${ }^{19}$ Nalezneme jej také u Filóna,$^{20}$ Simplikia ${ }^{21}$ a Alexandra z Afrodisiady citovaného Filoponem..$^{22}$ Simplikios jej používá spolu

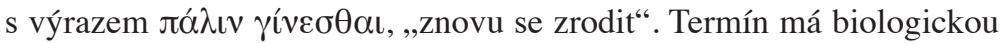
konotaci: označuje nové zrození, obrození.

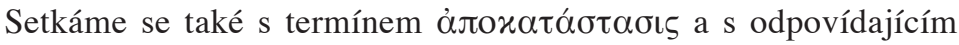
slovesem $\dot{\pi} \pi 0 \varkappa \alpha \theta i ́ \sigma \tau \alpha \sigma \theta \alpha$, jež znamenají „obnovení“, resp. „vrátit se na své dř́vější místo“. Substantivum má převážně astronomický význam: označuje návrat hvězd na stejnou pozici, ale také návrat ročních období. Má také politický význam a označuje obnovení politického režimu. Právě tento politický význam dominuje u slovesa, přičemž ozvuk tohoto významu můžeme nejspîs nalézt v Aristokleově textu o palingenezi. ${ }^{23}$ Oproti předchozímu termínu nenáleží tyto výrazy do biologického slovníku, ale odkazují k představě politického či kosmického řádu. Mohou tedy poukazovat na koncepci prozřetelnosti. To potvrzuje skutečnost, že podle zlomku citovaného Lactantiem používá tento termín Chrysippos ve svém pojednání $O$ prozretelelnosti. ${ }^{24}$

17 Takto R. Hoven, Stö̈cisme et stoüciens face au problème de l'au-delà, Paris 1971, str. 31. J. Barnes stejně tak jako A. Long a D. Sedley používá výraz „,věčný návrat“ (viz A. Long - D. Sedley, The Hellenistic Philosophers, Cambridge 1987).

18 Marcus Aurelius, Ad se ips. XI,1,3.

19 Eusebios, Praep.evan. XV,19,1.

20 Filón Alexandrijský, De aet. mundi, 76-77.

21 Simplikios, In Arist. Phys. 886,12-13.

22 Jan Filoponos, In Arist. De gen. et corr. 314,13-15.

23 ,Všechny věci ve světě jsou takto naprosto dokonale spravovány, jako ve státě řízeném těmi nejlepšími zákony.“ Aristoklés, De philosophia, VII, citovaný Eusebiem, Praep. evan. XV,14 (= SVF I,98).

24 Lactantius, Div. instit. VII,23 (= SVF II,263). Viz Eusebios, Praep. evan. $\mathrm{XV}, 19$, a Nemesios, De nat. hom. 38 (= SVF II,625). 


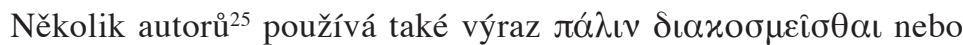

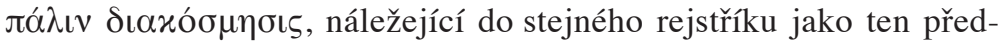
chozí, nebot' odkazuje k pojmu kosmického řádu: „[svět] se znovu uspořádává“".

Křest'anští autoři, kteří vykládají tuto nauku, využívají v souvislosti s návratem jednotlivců do identického stavu termíny ỏvó $\sigma \tau \alpha \sigma ı \varsigma$

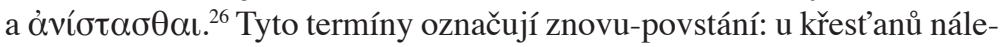
ží do slovníku vzkřrîsení a popisují ležícího mrtvého, který se znovu zvedne. Órigenés ovšem ujišt'uje, že se nejedná o termín používaný stoiky. ${ }^{27}$

Zato Chrysippův zlomek citovaný Lactantiem ${ }^{28}$ podle všeho skuteč-

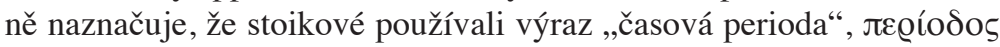

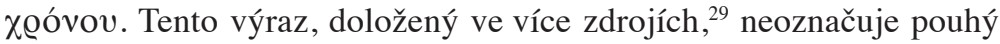
časový úsek, ale návrat času do jeho počátečního bodu, jelikož výraz $\pi \varepsilon$ Qíodos označuje okruh, návrat na počátek, zejména $\mathrm{v}$ případě oběhu hvězd. Opět zde tedy převažuje astronomický význam. Nauka tudíž není ani tolik naukou o „věčném návratu“ ve vlastním slova smyslu, jako spíše o periodickém návratu na začátek, o periodickém obrozování.

\subsection{Nauka podle Zénóna z Kitia}

Výše citovaný text, který Stobaios přebírá od Aria Didyma, ${ }^{30}$ vymezuje v hrubých obrysech nauku společnou třem prvním scholarchům stoické školy: vzplanutí a znovu uspořádání vesmíru identického s tím předchozím. Některé texty umožňují v těchto dvou bodech jasněji odlišit původní Zénónovu nauku ${ }^{31}$ od Chrysippových zpřesnění a oprav, ${ }^{32}$ zejména pokud jde o otázku, až kam onen návrat k dřivějšímu řádu sahá.

25 Stobaios, Ecl. I,20,171 (= DK 36; SVF I,107; SVF II,596); Eusebios, Praep. evan. XV,14 (= SVF I,98); tamt., XV,18,3 (DK 36).

26 Tatian, Orat. ad Graec., 3,23 a 6,5; Klement Alexandrijský, Strom. V,1,9,4; Órigenés, Contra Cels. V,20.

27 Órigenés, Contra Cels. V,20.

28 Lactantius, Div. instit. VII,23 (= SVF II,263).

29 Nemesios, De nat. hom. 38 (= SVF II,625); Órigenés, Contra Cels. IV,68 (=SVF II,625); V,20 (= SVF II,626); Eusebios, Praep. evan. XV,18,3.

30 Stobaios, Ecl. I,20,171, cit. výše, str. 109.

31 Eusebios, Praep. evan. XV,14 (= SVF I,98); Tatian, Orat. ad Graec., 3,22-28; Alexandr z Lykopole, Contra Manichœorum opiniones disputatio, zl. 46,1 in: A. Long - D. Sedley, The Hellenistic Philosophers (nezařazeno do SVF).

32 Plútarchos, De Stoic. repug. 39,1052c (= SVF II,604); týž, De commun. not. 36,1077e (= SVF II,1064); Lactantius, Div. instit. VII,23 (= SVF II,263); Alexandr z Afrodisiady, In Arist. An.pr. 180,31-36 a 181,25-31 (část in: SVF II,624). 


\subsubsection{Nauka o vzplanutí}

Podle Alexandra z Lykopole dokazoval Zénón nauku o vzplanutí následujícím sylogismem:

„Argument Zénóna z Kitia, podle něhož ,celý vesmír shoří‘, nebot’, jak tvrdí, ,vše, co hoří a má co spalovat, to spálí úplně. Nespálí snad i Slunce, které je ohněm, všechno, co má?‘ Domníval se, že z toho může vyvodit závěr: ,Celý vesmír shoří‘ “"33

Nauka je dobře doložena, a to také u Diogena Laertského.$^{34}$ Bůh je „tvořivý oheň“, který utváří celý svět a prostupuje jím, opracovává pasivní substanci světa (látku) na způsob zárodečného principu: démiurg z Timaia se stal imanentním principem, který je zároveň fyzikální (je to oheň) i biologický (je to zárodečný princip). Avšak tento oheň, jak je obsažený ve Slunci, je zároveň utvářející i stravující, jak dokládá Alexandrem přetlumočený argument: ${ }^{35}$ sluneční oheň tak nakonec pohltí ostatní nebeská tělesa a spálí celý svět.

\subsubsection{Opětné uspořádání světa}

„V jistých určených okamžicích celý svět vzplane a poté se zase znovu uspořádá. “36 Posloupnost příslovcí je obzvláště frapantní: časová násled-

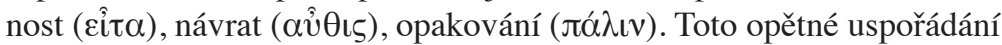
probíhá podle Aria Didyma skutečně přesně podle předchozího opětného uspořádání a obnovuje světový řád tak, jak byl předtím.

Jiné texty popisují proces opětného tvoření světa podle Zénóna: substance, která byla nejprve ve stavu ohně, se po průchodu vzdušným stádiem promění na vodu; ${ }^{37}$ část tekutiny zhoustne a stane se zemí, zatímco

33 Alexandr z Lykopole, Contra manich. 12.

34 DL VII,134.

35 Jak poznamenává J. Mansfeld, Providence and Destruction of the Universe in Early Stoic Thought, in: M. J. Vermaseren (vyd.), Studies in Hellenistic Religions, Leyden 1979, str. 151-155. Toto tvrzení se zdá protiřečit jinde doložené distinkci mezi pohlcujícím ohněm a ohněm tvořivým, jímž je Bůh. Avšak podle Kleanthova zlomku (SVF I,504) má Slunce obě vlastnosti.

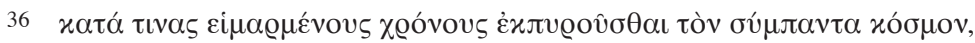

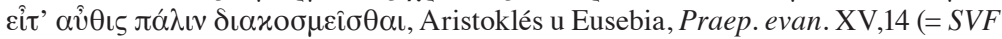
I,98).

37 Diskuse se S. Mouravieffem a S. Toulousem mne přesvědčila, že právě tak-

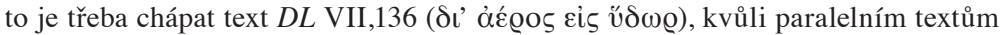

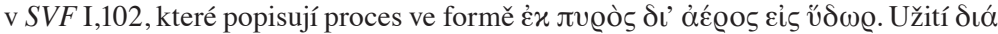


jiná část se zředí a znovu vytvoří vzduch a oheň. ${ }^{38}$ Tak získáme čtyři prvotní živly a „smíšením vznikají z těchto prvků rostliny, živočišstvo a ostatní rody“. 39

Avšak tento proces ještě nevysvětluje, že je svět znovu vytvářen identicky a že se vrací ke svému dřívějšímu řádu. Zde vstupuje do hry biologický model: „První oheň je jako semeno.“" Kosmogonie se tedy stává směsí biologie a fyziky. Připodobnění ohně k principu živého organismu zde umožňuje vysvětlit, že z tohoto jednoduchého látkového principu může dojít k ustavení řádu i tvoření živých bytostí. Tento oheň je ostatně bohem a semeno „obsahuje důvody všeho a prř́činy událostí minulých, přítomných i budoucích: je to jejich propletení, osudové propojení, vědění, pravda a zákon jsoucen, neporazitelný a nevyhnutelný““. ${ }^{41}$ Biologický determinismus a boží providencialismus vysvětlují, že vše probíhá znovu identicky.

\subsubsection{Kam až sahá tento návrat $\mathrm{k}$ dřívějšímu řádu?}

Tento návrat k dřivějšímu řádu sahá velmi daleko, nebot' dosahuje až k návratu týchž lidí: v podivné směsi osobností historických a mýtických jsou zmíněni Anytos a Melétos, Búsiris, Héraklés. ${ }^{42}$ A tito stejní lidé vykonají stejné činy: Anytos a Melétos obviní Sókrata, Búsiris zabije své hosty, Héraklés vykoná stejné práce. ${ }^{43}$

\subsection{Nauka podle Chrysippa}

\subsubsection{Nauka o vzplanutí}

Proces, který povede ke vzplanutí světa, se podle Chrysippa téměř neliší od toho, jak jej popsal Zénón. V pojednání O prožretelnosti (kde popisoval také identický návrat jednotlivců) popsal Chrysippos proces strávení látky. Duše světa přibývá na úkor těla, nebot' stravuje veškerou látku obsaženou ve světě. Vyvodil z toho důsledek, že zničení vesmíru není jeho smrtí, protože smrt je oddělení duše od těla: zde naopak dochází

ve významu ,průchodem přes“ může působit zvláštně, jedná se však o metaforické užití vycházející z lokálního smyslu daného stejným užitím ė̌ a عǐs, které je běžné.

38 DL VII,136 a 142.

39 Tamt. VII,142. (Český překlad cit. podle: Diogenés Laertský, Životy, názory a výroky proslulých filosofů, přel. A. Kolář, Pelhřimov $1995^{2}$, str. 297. - Pozn. překl.)

40 Stobaios, Ecl. I,20,171,2; Eusebios, Praep. evan. XV,14.

41 Eusebios, Praep.evan. XV,14.

42 Tatian, Orat. ad Graec. 3,24-25.

43 Tamt. 
k pohlcení těla duší. ${ }^{44}$ Tento popis jde dosti dobře dohromady s popisem

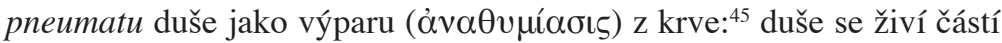
těla; stejně tak světová duše, jelikož se živí látkou světa, ji nakonec celou do sebe vstřebá. Potvrzuje se tak, že božský princip má v sobě pohlcující a stravující aspekt, který je soupodstatný s jeho aspektem tvůrčím a pořádajícím, stejně jako v Zénónově nauce.

\subsubsection{Opětovné uspořádání světa}

Také Chrysippova nauka o opětovném uspořádání světa je téměř totožná se Zénónovou. Zatímco však v Zénónově popisu se celý vesmír přeměnil na oheň, u Chrysippa se přeměňuje na éter:

„Chrysippos přrirovnává Dia a svět $\mathrm{k}$ člověku a prozřetelnost $\mathrm{k}$ duši. Když dojde ke vzplanutí, Zeus, který je jako jediný z bohů nezničitelný, se stáhne do své prozřetelnosti, a tak obé, protože se stalo tímtéž, přetrvává $\mathrm{v}$ jedné substanci éteru." ${ }^{46}$

Nezdá se, že by tato varianta zaváděla nějakou skutečně zásadní modifikaci, nebot' éter je popsán jako nebeský oheň. ${ }^{47}$ Bůh se stahuje do své duše: ,ponechán svým úvahám,“ jak řekne Seneka. ${ }^{48}$ Jelikož takto do sebe stažený bůh není ničím jiným než prozřetelností, nepřekvapí nás, že při obnově světa je vše znovu utvořeno podle přesně daného plánu.

\subsubsection{Kam až sahá tento návrat k dřívějšímu řádu?}

Teprve k otázce, kam až sahá tento návrat k dřívějšímu řádu, se Chrysippos vyjadřuje způsobem dosti odlišným od Zénóna. Ve spise $O$ prozřetelnosti píše toto:

44 ,Jelikož je smrt oddělením duše od těla, avšak duše světa se od něj neodděluje, nýbrž neustále narůstá, dokud v ní není látka zcela strávena, nesmíme říkat, že svět umírá.“ Plútarchos, De stoic. repugn. 39,1052c (= SVF II,604).

45 SVF II,778 a 783; srv. J.-B. Gourinat, Les Stö̈ciens et l'âme, Paris 1996, str. 18.

46 Plútarchos, De commun. not., 36,1077e (= SVF II,1064).

47 DL VII,137.

48 Seneca, Ep. 9,16. Srv. A. Long, The Stoics on World-Conflagration and Everlasting Recurrence, str. 23-24. (Český překlad cit. podle: Seneca, Další listy Luciliovi, přel. V. Bahník, Praha 1984, str. 28. - Pozn. překl.). 


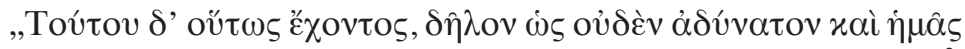

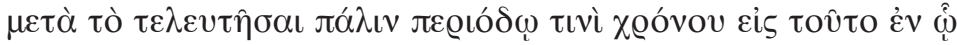

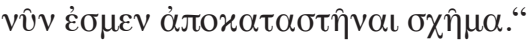

„Když se věci mají takto, je zjevné, že není nic nemožného na tom, abychom my sami po své smrti byli po uplynutí jistého času znovu obnoveni v té podobě, jakou máme nyní.“49

Je zjevné, že Chrysippos se vyjadřuje velmi opatrně. „Není nic nemožného“" neznamená: „Je to nutné.“ Kromě toho zde nenalezneme, tak jako u Zénóna, odkazy na mýtické či historické postavy, jako jsou Anytos a Héraklés. Jsme to my, kdo se můžeme vrátit ve stejné podobě. A konečně, Chrysippos nenaznačuje, že bychom mohli vykonat stejné činy: hovoří pouze o návratu ve stejné podobě. Také Alexandros, tentokrát s odvoláním na Chrysippův spis $O$ světě, neodkazuje ani na Anyta a Meléta, ani na vykonávání stejných činů:

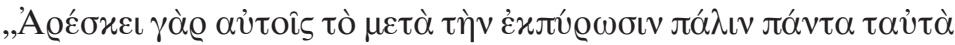

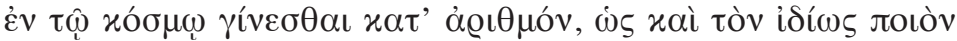

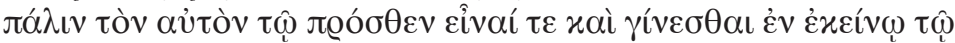

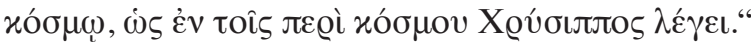

„Domnívají se, že po vzplanutí se ve světě znovu odehrají numericky tytéž věci, takže jsoucno nadané vlastní kvalitou je opět stejné jako to předchozí a existuje v tomto světě, jak říká Chrysippos ve svém pojednání $O$ světě. “50

Chrysippos se odkazoval na technický termín idíws Joเóv. Jedná se o jednu ze čtyř „kategorií“, které nejsou v našich pramenech systematicky vyloženy dř́ve nežli u Plótina, ačkoli narážky na ně nacházíme v jiných zdrojích, např́klad u Plútarcha a Sexta Empeirika. ${ }^{51}$ Пoıóv je to, čemu se dostalo nějaké kvality, jakožto zformované touto kvalitou, oproti substrátu, který je beztvarou látkou, jež tuto kvalitu přijímá,

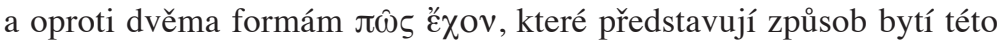

49 Lactantius, Div. instit. VII,23 (= SVF II,263).

50 Alexandr z Afrodisiady, In Arist. An.pr. 180,33-36.

$51 \mathrm{~K}$ této nauce viz zejména J.-J. Duhot, $Y$ a-t-il des catégories stö̈ciennes ?, in: Revue internationale de philosophie, 45, 1991, str. 220-244, a J.-B. Gourinat, La dialectique des stö̈ciens, Paris 2000, str. 129-136. 
kvalifikované substance. Stoická nauka proti sobě staví jsoucno mající vlastní kvalitu (iðíws Joıóv), jako jsou Sókratés nebo Dión, a jsoucno

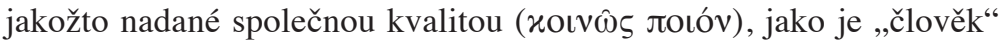
nebo „kůn̆“. Z uvedeného svědectví je tedy jasné, že pro Chrysippa se nevrátí pouze živočišné nebo rostlinné druhy, ale také totožní jedinci.

O stránku později Alexandros z Afrodisiady upřesňuje, že jsoucna, která se v rámci periodických obnov vracejí, se vrátí s tak minimálními rozdíly, že jim to nezabrání, aby byla totožná:

„Pokud jde o později vznikající jsoucna nadaná vlastní kvalitou, oproti dřívějším jsoucnům se proměňují pouze co do některých vnějších akcidentů, srovnatelných s proměnami, kterými v průběhu života prochází Dión, zůstávaje tentýž, a které ho nečiní jiným. Vždyt’ se nestane jiným, pokud měl například dříve na obličeji bradavice a později je nemá. Ř́kají, že ke srovnatelným proměnám dochází mezi jsoucny nadanými vlastní kvalitou z jednoho a druhého světa." ${ }^{\text {52 }}$

Promlouvá zde stále ještě Chrysippos? Pravděpodobně ano, ale na první pohled jisté to není.

\section{Problémy s naukou a debaty uvnitř školy}

\subsection{Problém cyklického a periodického času}

Ve stoické nauce o periodickém obrození se nacházejí dvě propojené teze: teze o vzplanutí na konci jistého časového období a teze o věcech, které se ve stejném sledu totožné vracejí, jako hvězdy, které při každém oběhu následují tutéž dráhu. Právě spojení těchto dvou tezí odlišuje stoickou verzi nauky od té pýthagorejské, jak ji představuje zejména Órigenés.$^{53}$ Pýthagorejská nauka neobsahuje vzplanutí, což je představa, kterou si Zénón podle všeho vypůjčil od Hérakleita: k obrození světa dochází pouze po uplynutí „Velkého roku“, což je cyklus odhadovaný na několik tisíc let, po němž se hvězdy vrátí na své počáteční místo a započnou znovu tentýž oběh. V této verzi věčného návratu probíhají pozemské věci totožně, po vzoru nebeských jevů, a je nutné, aby se

52 Alexandr z Afrodisiady, In Arist. An.pr. 181,25-31.

53 Órigenés, Contra Cels. V,21. 
Sókratés znovu narodil těm samým rodičům. Zdá se, že stoikové nauku o Velkém roce přijali, jak dokládá tento Nemesiův text: ${ }^{54}$

„Stoikové říkají, že když se planety vrátí co do délky i šir̂rky do stejného nebeského znamení, kde byly každá na počátku, když byl utvořen svět, dojde v ohlášeném časovém období ke vzplanutí a ke zničení jsoucen a svět se znovu od začátku navrátí ve stejném stavu. Stejně jako hvězdy znovu obíhají po stejné dráze, naplní se neodchylně každá z událostí předchozího období.“"55

To znamená, že pozemské a lidské události jsou pojímány po vzoru nebeských oběhů. Jestliže je čas pro stoiky extensí pohybu světa, pak čas i svět společně znovu začínají stejným zpo̊sobem, poté co se svět navrátil do svého počátečního stavu. Stejně jako říkáme ,zítra ve stejnou hodinu“ nebo ,přríští rok ve stejný den“, i ve Velkém roce se všechno opakuje ve stejný den a stejnou hodinu. To ale představuje obtíž, formulovanou v pseudo-Aristotelových Problématech (XVII,3): jestliže čas tvoří kruh a lidské dějiny také, pak nejsme oproti obyvatelům Tróje pozdější, ani oni nepředcházejí nám (916a38-39). Jistě z tohoto důvodu někteří stoikové tvrdili, že ten, kdo se vrací, není Sókratés, ale bytost, která se od Sókrata nelišíi ${ }^{56}$ Toto řešení však není př́liš uspokojivé, nebot' problém cyklického času se tím zdá být nedotčen.

Ve skutečnosti existuje tento problém cyklického času pouze v pýthagorejské teorii a nikoli u stoiků. Existuje totiž, pouze pokud je čas kruh, bez začátku a bez konce (916a37-38). Avšak čas stoického věčné-

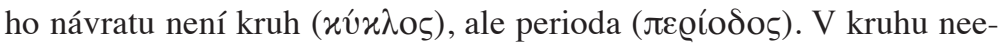
xistuje směr a není tam ani začátek, ani konec. Perioda má směr: oproti mýtu v Politikovi se čas nevrací zpátky. A ve stoické periodě je i začátek i konec, které vyznačuje vzplanutí. Jestliže je čas extenzí pohybu světa, pak jelikož během vzplanutí není svět, není ani čas. Čas světa tak nikdy nespojí svůj konec se začátkem, nebot' mezi začátkem a koncem je ono přerušení, jímž je vzplanutí.

Čas stoiků tedy není časem cyklickým, nýbrž periodickým: před námi a po nás existuje nekonečně časů podobných tomu našemu, které našemu skutečně předcházejí nebo po něm následují.

54 Eusebios, Praep.evan.XV,19 se explicitně odvolává na Velký rok jako na trvání světa mezi dvěma vzplanutími, stejně jako Filoponos, In Ar. Gen. et corr. 314,13.

55 Nemesios, De nat. hom. 38 (= SVF II,625).

56 Órigenés, Contra Cels. IV,68. 


\subsection{Problém numerické identity}

Mezi stoiky, kteří nauku přijímali, se hlavní debata týkala otázky identity jednotlivců $\mathrm{v}$ různých periodách. Jsou v každém následujícím světě jednotlivci zcela stejní, bez rozdílu? Někteří stoikové tuto tezi podle jistých zdrojů hájili ${ }^{57} \mathrm{~V}$ této verzi ,„še proběhne stejným způsobem a bez rozdílu, až do nejmenšího detailu“ “. ${ }^{58}$ Órigenés nabízí ještě úchvatnější popis než Nemesios:

„Sókratés bude znovu synem Sófroniska a Athéňanem, a Fainareté se znovu vdá za Sófroniska a zplodí jej.... Sókratés bude vzkříšen, povstav ze semene Sófroniskova; zformuje se v lůně Fainaretině, vyučí se v Athénách a stane se filosofem, stejně tak jeho dřívější filosofie bude vzkř́íšena a rovněž se nebude odchylovat od té předchozí. A Anytos s Melétem také budou vzkříšeni, znovu obviní Sókrata a rada na Areopágu ho znovu odsoudí. ... Sókratés bude nosit šaty, které se nebudou odchylovat od těch z předchozího období, bude žít v chudobě, která se nebude lišit, a v obci Athény, která se nebude lišit od té z př́edchozího období. “59

Podle téhož Órigena však někteří stoikové opravili absurdity plynoucí z této nauky a tvrdili, že znovu existovat nebude tatáž osoba, byt' nebude odlišná.$^{60}$ Jiní naopak tvrdí, že budou prrítomné drobné rozdíly, které neohrozí identitu. ${ }^{61}$

Podle J. Barnese ${ }^{62}$ a A. Longa ${ }^{63}$ tudíž existují tři nebo čtyři formy nauky:

1. stejní jednotlivci až do nejmenších detailů, což implikuje numerickou identitu; ${ }^{64}$

57 Nemesios, De nat. hom. 38 (= SVF II,625); Órigenés, Contra Cels. IV,20 (= SVF II,628), IV,68 (= SVF II,625) a V,20 (= SVF II,626).

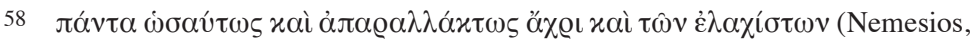
De nat. hom. 38,112,3).

59 Órigenés, Contra Cels. V,20.

60 Tamt. IV,68.

61 Tamt. V,20; Alexandr z Afrodisiady, In Arist. An.pr. 181,25-31.

62 J. Barnes, La doctrine du retour éternel, str. 9-12.

63 A. Long, The Stoics on World-Conflagration and Everlasting Recurrence, str. 26-31; viz také A. Long - D. Sedley, The Hellenistic Philosophers, I, str. 312.

64 Nemesios, De nat. hom. 38 (= SVF II,625); Alexandr z Afrodisiady, In Arist. An. Pr. 180,31-36; Simplikios, In Arist. Phys. 886,12-15. 
2. nerozlišitelné exempláře stejného typu, ${ }^{65}$

3. numerická identita s nepatrnými, vnějšími a akcidentálními odlišnostmi, jako jsou bradavice na obličeji, ${ }^{66}$

4. exempláře stejného typu s drobnými rozdíly. ${ }^{67}$

Podle J. Barnese jsou možnosti (3) a (4) stejné, ale A. Long se domnívá, že Alexandrem zmiňovaná teze o nepatrných rozdílech ${ }^{68}$ implikuje numerickou identitu, zatímco stoikové „stydící se“ za nauku, o nichž hovoří Órigenés ${ }^{69}$ ji nepřijímají. Ve skutečnosti je Órigenův text dosti zmatený, nebot' prohlášení zahanbených stoiků předchází popisu identitní orthodoxie v právě citované pasáži.

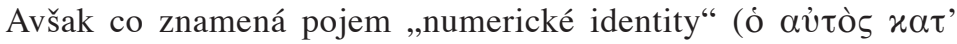

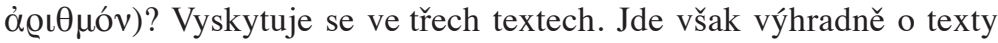
aristotelských komentátorů, Alexandra, Filopona citujícího Alexandra a Simplikia. ${ }^{70}$ Ba co víc, v Alexandrově textu, kde se vykládá Chrysippova nauka, je zřejmé, že Chrysippos říká, že se vrací stejný kvalifikovaný jednotlivec, což teprve Alexandros vykládá v termínech numerické identity. ${ }^{71}$ Jak jasně ukazuje Filoponův text, výraz „numerická identita“ pochází ve skutečnosti od Aristotela: nachází se v pasáži spisu De generatione et corruptione, kterou Filoponos v danou chvíli komentuje, totiž II,11,338b18. Aristotelés zde tvrdí, že pokud existují jsoucna, která se vracejí jako numericky identická, mají nutnou, tj. nezanikající podstatu. Filoponův text vysvětluje, že není možné, aby se „numericky vraceli““ jedinci, jejichž podstata podléhá zániku, jako je Sókratés, nebot' „není možné existovat přerušovaně jako jeden a numericky tentýž“ ${ }^{72}$ pouze Slunce, jehož podstata nezaniká, může zůstat numericky identické, a to i po vzplanutí. Být numericky identický předpokládá u Filopona trvalost,

\footnotetext{
65 Órigenés, Contra Cels. IV, 68.

66 Alexandr z Afrodisiady, In Arist. An. pr. 181,25-31.

67 Órigenés, Contra Cels. V,20.

68 Alexandr z Afrodisiady, In Arist. An.pr. 181,25-31.

69 Órigenés, Contra Cels V,20.

70 Alexandr z Afrodisiady, In Arist. An.pr. 180,31-36; Filoponos, In Ar. De gen. et corr. 314,9-22; Simplikios, In Arist. Phys. 886,12-15.
}

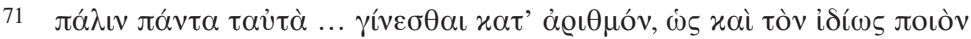

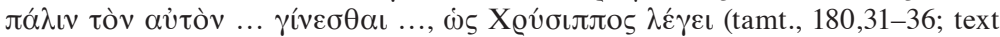
přeložen výše, str. 116).

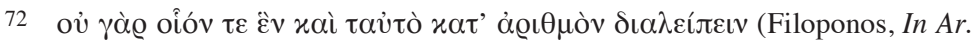
De gen. et corr. 314,18-19). 
proto zavrhuje tezi o identitě v palingenezi. Avšak stoická nauka právě není naukou o trvalosti substance, nebot' při vzplanutí vše zaniká. ${ }^{73} \mathrm{~V}$ daném problému tak nejde o identitu numerickou, ale o identitu ne-numerickou. Problém je následující: jestliže se nějaké jsoucno zrodí znovu, postrádá pak jakékoli odlišnosti, nebo se nějak lišíi Je stejné, nebo ne? Co to znamená být stejný?

\subsection{Problém identity a odlišnosti}

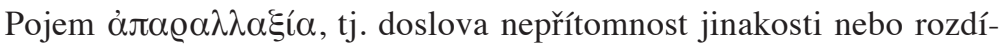
lu (který se často překládá poněkud zavádějícím způsobem za pomoci leibnizovského termínu „,nerozlišitelnosti“), byl do stoicismu zaveden Zénónem, v rámci diskuse o uchopující představě ( $\alpha \alpha \tau \alpha \lambda \eta \pi \tau \iota x \eta ̀ ~$ $\phi \alpha v \tau \alpha \sigma i ́ \alpha) .{ }^{74}$ Jde o představu, která ,ppochází z toho, co je, odpovídá tomu, co je, a je taková, že by nemohla pocházet $\mathrm{z}$ něčeho, co by neby10 “ ${ }^{75}$ Arkesilaos namítnul Zénónovi, že existují falešné představy nerozlišitelné od těch pravdivých a že jsou jsoucna, mezi kterými není žádný rozdíl: dvojčata, vejce, sériově vyrobené sochy. $\mathrm{V}$ tomto rámci využíval

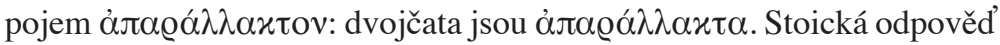
zněla, že neexistují dvě stejná vejce, dvě stejná dvojčata, žádná dvě zrnka písku, která by byla naprosto identická. ${ }^{76}$

Důsledek je tedy jasný: pokud nejsou žádná dvě individua

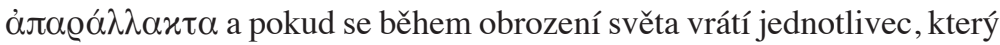

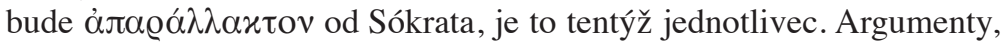

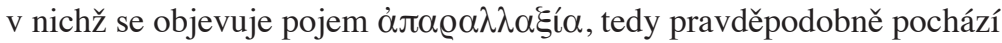
od Zénóna. Ostatně když Órigenés ${ }^{77}$ vykládá nauku o návratu bez sebemenší odlišnosti, až po Sókratův plášt', vztahuje tuto nauku k Zénónovi ve větě, kterou Arnim vypustil, nebot' chtěl uvedený zlomek připsat Chrysippovi, a nikoli Zénónovi. ${ }^{78}$ Že se zde jedná o nauku Zénónovu, a nikoli Chrysippovu, je tím pravděpodobnější, že - jak jsme

73 Órigenés vysvětluje, že právě v tom spočívá rozdíl mezi stoickou naukou a křest'anskou naukou o vzkř́íšení: u stoiků je znovu ustavený jedinec identický, ačkoli z něho nic nezbylo (ani duše nepřežila, nebot' shořela během vzplanutí), zatímco pro křest’any, ,stejně jako klas povstává ze zrnka obilí, tak se v těle nachází jakýsi zárodečný výměr, který nezaniká a z kterého ,povstává‘ tělo ve své nezničitelnosti“. Órigenés, Contra Cels. V,23.

74 Srv. J.-B. Gourinat, Les stö̈ciens et l'âme, str. 71-75.

75 Sextos Empeirikos, Adv. math. VIII, 248; Cicero, Acad. pr. II,77.

76 Cicero, Acad.pr. II,56-57; II,87.

77 Órigenés, Contra Cels. V, 20.

78 SVF II,626. 
viděli - ostatní svědectví explicitně připsaná Zénónovi také zmiňují Anyta a Meléta, zatímco úryvek z Chrysippa citovaný Lactantiem hovoří o já.

Stoikové se však potýkali i s jinými problémy, než byl problém uchopující představy. Jedním z nich byl růst. ${ }^{79}$ Je to též otázka Théseovy lodi, po staletí uchovávané v Athénách, jejíž všechny části byly postupně vyměněny. Byla to tatáž lod', nebo ne? Když jednotlivec roste, přibývá jeho látky. Také se po celý průběh svého života tělesně mění. Je tentýž? Podle argumentu zaznamenaného Alexandrem z Afrodisiady ${ }^{80}$ pokud má někdo bradavici a následně ji již nemá, zůstává tentýž. Tento argument je

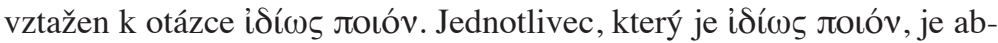
solutně odlišný od ostatních jednotlivců, ale v průběhu času také získává rozdíly ( $\pi \alpha \varrho \alpha \lambda \lambda \alpha \gamma \alpha i ́)$, které neovlivňují jeho identitu.

První, kdo rozvinul tento pojem iđó́ $\omega \varsigma$ Jotóv, je přitom zjevně Chrysippos, čemuž nasvědčuje kvazi-citace ze spisu $O$ světě.$^{81}$ Zdá se tedy, že Chrysippos, v odlišném kontextu nežli Zénón, zjemnil svůj pojem identity. Identita není pouze to, co mne odlišuje od druhého, takže jsem jiný než druhý, byt' téměř neznatelně. Identita je také to, co způsobuje, že zůstávám sebou samým, i když se měním. To, z čeho tato identita vychází, je má vlastní kvalita.

Jelikož pojem numerické identity není stoický, existují pouze dvě nebo tři verze stoické nauky: opětné objevení jednotlivce, který se neliší od Sókrata a je s ním totožný (původní Zénónova nauka); možná opětné objevení jedince, který se neliší od Sókrata a není Sókratem (abychom se vyhnuli problému cyklického času); opětné objevení stejného kvalifikovaného jednotlivce s drobnými rozdíly, které neovlivňují jeho identitu, což je pravděpodobně Chrysippova hypotéza.

Samožrejmě, zmíněné rozdíly mohou být pouze nepatrné. Znamená to však, že mohu v pozdějším světě jednat jinak? Až na nepatrné detaily nikoli. To dobře ukazuje Órigenem zvolený příklad: Sókratés se vrátí, vzešlý ze spermatu Sófroniska a počatý v lůně Fainarety. Činy se tedy nemohou lišit, nebot' pak by se neobjevili znovu titíž jednotlivci: kdyby se Sófroniskos a Fainareté nespojili, nebylo by Sókrata. Mohou se tedy vyskytovat pouze nepatrné změny, které neovlivní ani chod dějin, ani identitu. Chrysippos nepochybně tvrdil, že pokud existuje individuální

79 K této otázce viz D. Sedley, The Stoic Criterion of Identity, in: Phronesis, 27, 1982, str. 255-275.

80 Alexandr z Afrodisiady, In Arist. An.pr. 181,25-31.

81 Tamt. 180,35-36. 
palingeneze (a nikoli pouze kosmická obnova a obrození druhů), pak se muselo všechno stát znovu stejně, pouze s nepatrnými rozdíly. Důsledek je však nutný, pouze pokud je taková i hypotéza. Domníval se Chrysippos, že tomu tak je? Podle Lactantia říkal: „Není to nemožné.“ Možná právě toto dovedlo Zénóna z Tarsu a Panaitia k pochybnosti.

\section{Závěr}

Pro Nietzscheho je věčný návrat, coby „věčná nicota“, extrémní formou nihilismu, věčnou absurditou (Sinnlose). ${ }^{82}$ Věčný návrat je pro něj sinnlos, zbavený významu, nebot' tam, kde není konce, není ani cíle. Pro stoiky však má věčný návrat smysl. V protikladu vůči Aristotelovi jim je jasné, že svět není věčný: jako všechno živé má svůj počátek a svůj konec. Takový je zákon života. Avšak jestliže prvotní látka a bůh nikdy nezanikají, musí se svět periodicky obnovovat. Ale když tak činí, musí tak činit pokaždé jiným způsobem? Pokud se stoikové domnívali, že tomu tak není, je to pravděpodobně dáno tím, že bůh je prozřetelnost. Tvoří tedy nejlepší ze světů. Kdyby pokaždé vytvořil jiný svět, šlo by o absurdní hříčku. Věčný návrat je tedy vyjádřením božské racionality. Pro Tatiána jde o absurdní nauku, protože oproti vzkřrišení, k němuž do-

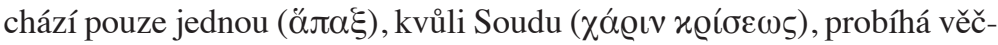

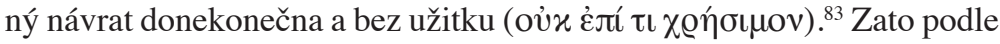
Chrysippa sehrává bůh stále ten samý kus, protože je to ten nejlepší. Dojít k takovému závěru vyžadovalo velkou lásku ke světu. Je zvláštní, že stejná nauka se mohla Chrysippovi jevit jako vyjádření božské prozřetelnosti a Nietzschemu jako projev vůle k moci a absurdity.

Přeložil Jacques Joseph

82 „,Die ewige Wiederkehr.' Das ist die extremste Form des Nihilismus: das Nichts (das ,Sinnlose') ewig!“ F. Nietzsche, Werke in drei Bänden, vyd. K. Schlechta, München 1954-1956, III, str. 852. (Citujeme podle odlišného vydání než autor, autorovu citaci se nepodařilo dohledat. - Pozn. překl.)

83 Tatian, Orat. ad Graec., 6,15-21: „I proto věříme, že po skončení světa dojde k tělesnému vzkříšení, ale ne tak, jak učí stoikové, že ty též věci po způsobu jakýchsi cyklických period stále vznikají a zanikají bez jakéhokoli užitku. Konec ,našich věkư nastane jen ,jednou' a s konečnou platností a dojde ke shromáždění, avšak pouze lidí, aby byli souzeni.“ Výraz v uvozovkách, ,našich věků jednou“ (䀠 $\alpha \xi$

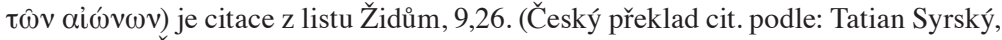
Promluva k Řekům, přel. P. Dudzik, Praha 2016, str. 89 n. - Pozn. překl.) 